\title{
Development of Strategies to Minimize the Risk of Listeria monocytogenes Contamination in Radish, Oriental Melon, and Carrots
}

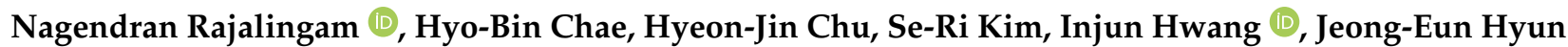 \\ and Song-Yi Choi * (i)
}

check for updates

Citation: Rajalingam, N.; Chae, H.-B.; Chu, H.-J.; Kim, S.-R.; Hwang, I.;

Hyun, J.-E.; Choi, S.-Y. Development of Strategies to Minimize the Risk of Listeria monocytogenes Contamination in Radish, Oriental Melon, and Carrots. Foods 2021, 10, 2135. https://doi.org/10.3390/ foods10092135

Academic Editors:

Elena González-Fandos

Received: 30 July 2021

Accepted: 6 September 2021

Published: 9 September 2021

Publisher's Note: MDPI stays neutral with regard to jurisdictional claims in published maps and institutional affiliations.

Copyright: (c) 2021 by the authors. Licensee MDPI, Basel, Switzerland. This article is an open access article distributed under the terms and conditions of the Creative Commons Attribution (CC BY) license (https:/ / creativecommons.org/licenses/by/ $4.0 /)$.
Microbial Safety Team, National Institute of Agricultural Sciences, Rural Development Administration, Wanju 55365, Korea; nagendranrajalingam@gmail.com (N.R.); hyobin3811@korea.kr (H.-B.C.); chj07079@korea.kr (H.-J.C.); seri81@korea.kr (S.-R.K.); injun0370@korea.kr (I.H.); jeongeunh@korea.kr (J.-E.H.)

* Correspondence: songechoi@korea.kr

Abstract: Contamination by Listeria monocytogenes in packaged produce is a major concern. The purpose of this study was to find natural and affordable sanitizers to reduce L. monocytogenes contamination in agricultural products. Organic acids, ultraviolet-C (UV-C), and ethanol were analyzed either alone or in combination to assess their ability to reduce L. monocytogenes population in radish, oriental melon, and carrot samples. In radish samples, 3\% malic acid combined with UV-C at a dosage of $144 \mathrm{mj} / \mathrm{cm}^{2}$ significantly reduced ( $>4 \log \mathrm{CFU} / \mathrm{g}$ ) the population of L. monocytogenes $(1.44 \pm 0.5)$ compared to the control sample $(5.14 \pm 0.09)$. In the case of the melon samples, exposure to UV-C at a dosage of $144 \mathrm{mj} / \mathrm{cm}^{2}$ combined with $3 \%$ lactic acid (2.73 \pm 0.75$)$ or $50 \%$ ethanol $(2.30 \pm 0.01)$ was effective against $L$. monocytogenes compared to the control sample (5.10 \pm 0.19$)$. In carrot samples, $3 \%$ lactic acid combined with $144 \mathrm{mj} / \mathrm{cm}^{2}$ dosage UV-C reduced L. monocytogenes population $(4.48 \pm 0.25)$ more than in the control sample $(5.85 \pm 0.08)$. These results reveal that sanitizers that are effective for one crop are less effective for another crop indicating that effective prevention methods should be customized for each crop to prevent pathogen cross contamination during postharvest washing.

Keywords: Listeria monocytogenes; postharvest washing; microbial contamination; agricultural products; sanitizers; organic acids; ethanol; UV-C

\section{Introduction}

Listeria monocytogenes, a psychotropic pathogen associated with consumption of fresh produce is one of the most important foodborne pathogens that causes listeriosis, a serious life-threatening invasive disease [1]. According to the Centers for Disease Control and Prevention (CDC), an estimated 1600 people are diagnosed with listeriosis and about 260 people die every year [2]. Immunocompromised individuals, elderly people over 65, and pregnant women and their neonates are most likely to be affected by listeriosis [3]. The number of agricultural produce related L. monocytogenes outbreaks has increased in recent years. For instance, the United States Food and Drug Administration (FDA), along with the CDC, reported several multistate outbreaks of L. monocytogenes infections linked to enoki mushrooms [4], prepackaged caramel apples [5], and frozen vegetables [6] in the past five years. Melon-associated L. monocytogenes outbreaks have also been reported in previous years [7,8]. In addition, the prevalence of L. monocytogenes in fresh produce including lettuce [9], mushrooms [10], cabbage [11], carrots [12,13], radishes [14,15], corn [16], parsley [17], strawberries [10], watercress [18], celery [19], red peppers [20], cucumbers [21], and several other salad vegetables [22] has been reported through microbiological risk assessment surveys from various countries.

Agricultural products can acquire pathogens through several sources during farming (contaminated soil, raw materials, livestock manure, irrigation water, pets, or farm workers) 
or at any step during the postharvest process (peeling, trimming, cutting, washing, and packing) [23]. The postharvest washing step at a commercial scale removes field-acquired contamination such as dirt, chemicals, cell exudates, and reduces microbial load up to 1- to 2- $\log$ [24]. However, most pathogens attach to the food surface firmly and form biofilms [25] or become internalized in the edible parts of the plant that are hard to remove by rinsing with cold water [26]. In some cases, the washing water can be a source of cross contamination that can lead to the distribution of pathogens between clean and contaminated food products [27]. Hence, washing the food products with tap water alone in a water bath is inefficient to control pathogen contamination unless effective sanitizers are combined with water [28].

Developing prevention technologies to eradicate microbial contamination in agricultural products is very crucial. Several chemical (chlorine [29], chlorine dioxide [30], paracetic acid [31], ozone [32,33], sodium hypochlorite, and acidified sodium chlorite [34]) methods have been applied on food products to control L. monocytogenes contamination. However, these methods can lead to disinfection byproduct (DBPs) formation, and chemical residues left on the food surfaces after washing could affect the quality and safety of the food products and may cause serious health risks to consumers [35]. Nonthermal food processing physical methods such as high hydrostatic pressure [36], pulsed light [37], ultrasound [38,39], plasma-activated water [40], cold plasma-activated hydrogen peroxide aerosol [41], dielectric barrier discharge gas plasma [42,43], low dose irradiation [44], etc., have been shown to be efficient in inactivating L. monocytogenes and other foodborne pathogens in fresh produce. However, these methods may require huge investments [45] and high operational costs [46] along with more processing time [47], which may be reflected the cost of the food products. Hence, it is necessary to find natural, affordable, and nontoxic interventions that can eliminate pathogens. Nevertheless, any disinfection method can only reduce the pathogen population in contaminated fresh produce but cannot completely decontaminate produce.

Organic acids can be used as alternatives for chlorine based chemical sanitizers as they are generally recognized as safe (GRAS) to add to foods [28]. Antimicrobial properties of organic acids depend on their dissociation constants or $\mathrm{pKa}$ values [48]. At low $\mathrm{pH}$, the undissociated portion of the organic acids diffuse through the cell membranes and alter the internal chemical equilibrium of the microbial cells, which severely impairs their metabolism [49] and other cellular processes such as DNA replication and protein synthesis leading to cell death [50]. Ultraviolet (UV-C) treatment is one of the most effective method to inactivate pathogens as it is nonthermal and does not leave any toxic residues in foods [51] and consumer safe as it does not alter the properties of the food products [52]. UV-C radiation impairs the genomic DNA of bacteria by inducing pyrimidine dimers, which consequently inhibits transcription and replication, which eventually causes cell death [53]. Ethyl alcohol (ethanol) is broadly used in many research and clinical labs as disinfectants to kill microbes. In addition, ethanol produced during fermentation of foods and drinks has been shown to have a preservative function against microorganisms [54]. Ethanol increases membrane permeability and sensitizes microbial cells to osmotic stress and $\mathrm{pH}$ stress leading to cell death [55].

The efficiency of sanitizers depend on the type of food and characteristics of the sanitizing method applied [56]. Although the standalone bactericidal effects of organic acids, UV-C, and ethanol have been well documented on fresh produce $[48,57,58]$, studies regarding their combinational effects and application during produce washing is still limited. In this study, we analyzed the efficiency of organic acids, UV-C, and ethanol either alone or in combination to reduce L. monocytogenes population in radish, oriental melon, (melon) and carrot samples to minimize the risk of disease outbreak through agricultural products. As all the disinfection strategies were performed on a laboratory scale without pilot scale trials, several physiochemical parameters in these methods should be optimized in detail before implementing in an industrial setup. 


\section{Materials and Methods}

\subsection{Sample Preparation and Inoculation}

Three different isolates of Listeria monocytogenes (NX1-serotype 3c str. 10-5027 [Genome ID: CP007196]; 2YC-serotype 1/2a str. 10-0934 [CP007200]; B2-FORC_049 [CP016629]) were revived from glycerol stock $\left(-80^{\circ} \mathrm{C}\right)$ on tryptic soy agar-yeast extract (TSA-Ye; Oxoid Ltd., Basingstoke, UK) plates prior to each experiment. Single colonies of the bacteria from the TSA-Ye plates were picked and inoculated separately in tubes containing tryptic soy broth-yeast extract (TSB-Ye; Oxoid Ltd., Basingstoke, UK) and incubated at $37^{\circ} \mathrm{C}$. After $24 \mathrm{~h}$, the bacterial cells were collected by centrifugation at $3000 \times \mathrm{g}$ for $10 \mathrm{~min}$ (Labogene 1736R, Gyrozen Co. Ltd., Seoul, Korea) and washed 2 times with $1 \mathrm{~mL}$ phosphate-buffered saline (PBS; Biosesang, Seongnam, Korea) (pH 7.3) buffer suspension. The washed isolates were mixed together as a cocktail after centrifugation by suspending the pellet with $5 \mathrm{~mL}$ PBS buffer up to a concentration of $0.5 \mathrm{OD}_{600}\left(1.5 \times 10^{7} \mathrm{CFU} / \mathrm{mL}\right)$.

The radish, melon, and carrot samples purchased from local markets in Korea were warmed to room temperature and cut into small pieces [carrot- $2 \times 2 \mathrm{~cm}(8-10 \mathrm{~g})$; melon- $2 \times 5 \times 1 \mathrm{~cm}(10-14 \mathrm{~g})$; radish- $2 \times 2 \mathrm{~cm}(8-10 \mathrm{~g})$ ] (Figure 1A). The cut vegetables were treated with $70 \%$ ethanol for $5 \mathrm{~min}$, followed by washing with sterile distilled water [59], and dried on a clean bench until the vegetables were completely dried ( $30 \mathrm{~min}-1 \mathrm{~h})$. The cut vegetables were spot-inoculated with $100 \mu \mathrm{L}$ of L. monocytogenes cocktail suspension $(10 \mu \mathrm{L}$ in 10 spots around each piece of vegetable). After spot-inoculation, the cut vegetables were dried on a clean bench at room temperature for around $30 \mathrm{~min}$ to $1 \mathrm{~h} / \mathrm{until}$ it is dried. For experiments with whole (intact) vegetables (Figure 1B), bacterial suspensions were sprayed on the vegetable surfaces and air-dried before treatment. Equal volumes of spray [59] collected in $15 \mathrm{~mL}$ falcon tubes were used as control.

\subsection{Individual Treatments}

Organic acids [Acetic acid (pH-2.38), L(+)-Ascorbic acid (pH-2.36), Citric acid anhydrous (pH-1.80), and DL-Malic acid (pH-2.38) (Daejung Chemicals and Metals Co. Ltd., Siheung, Korea)], Lactic acid (pH-2.40) (Kanto Chemical Co. Inc., Tokyo, Japan), and $\mathrm{L}(+)$ Tartaric acid (pH-1.82) (Sigma-Aldrich Inc., Merck KGaA, Darmstadt, Germany) prepared at $1 \%$ and $3 \%$ concentrations were filter sterilized with $0.22 \mu \mathrm{m}$ pore size MFMillipore $^{\mathrm{TM}}$ membrane filters (Merck KGaA, Darmstadt, Germany). To investigate the individual efficacy of organic acids against $L$. monocytogenes in carrot, melon, and radish samples, the L. monocytogenes spot-inoculated cut vegetables were immersed (dipping) in a sterile filter bag containing $60 \mathrm{~mL}$ of the organic acids for $5 \mathrm{~min}$. For ethanol treatment, the cut vegetables were dipped in sterile filter bags containing $60 \mathrm{~mL}$ of food-grade fermented ethanol (Ethanol Supplies World Co., Ltd., Jeonju, Korea) prepared at different concentrations $(5 \%, 10 \%, 20 \%, 50 \%$, and $70 \%)$ for 1 and $3 \mathrm{~min}$. The efficacy of UV-C ( $254 \mathrm{~nm})$ treatment was analyzed on cut vegetables with different intensities $\left[4.7 \mathrm{~mW} / \mathrm{cm}^{2}(15 \mathrm{~cm}\right.$ distance), $2.4 \mathrm{~mW} / \mathrm{cm}^{2}(30 \mathrm{~cm})$, and $\left.1.2 \mathrm{~mW} / \mathrm{cm}^{2}(45 \mathrm{~cm})\right]$ and time points $(5,10,15$, and $30 \mathrm{~min}$ ) (Figure 1A). For control treatment, the cut vegetables were treated with $60 \mathrm{~mL}$ DW in sterile filter bags for $5 \mathrm{~min}$. After treatment, the cut vegetables were immediately transferred to a stomacher bag containing 9x volume of BD Difco ${ }^{\mathrm{TM}} \mathrm{D} / \mathrm{E}$ (Dey-Engley) neutralizing broth (D/E broth; Difco, Becton Dickinson Co., Sparks, MD, USA) to neutralize the residual effects of sanitizers. All the treatments were performed at room temperature $\left(25^{\circ} \mathrm{C}\right)$. 


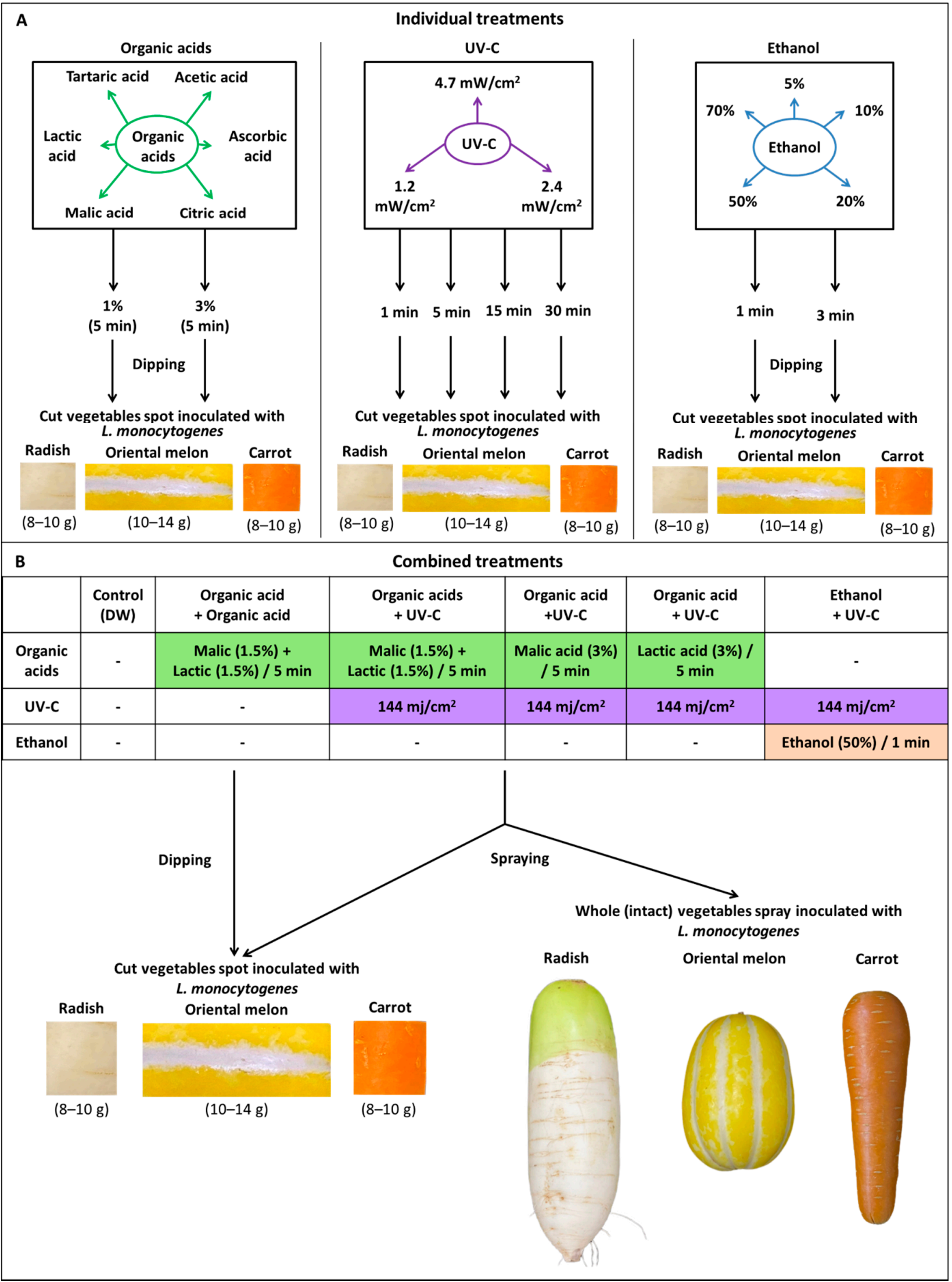

Figure 1. Schematic representation of the different treatment strategies that were applied on cut and intact vegetables. The individual (A) and combined (B) efficacy of organic acids, UV-C, and ethanol against L. monocytogenes were analyzed on cut and intact radish, oriental melon, and carrot samples. 


\subsection{Combined Treatments}

Based on the results of individual treatments, we analyzed the combined efficacy of the following treatments: organic acids, malic acid, or lactic acid at $3 \%$ concentrations combined with UV-C at $30 \mathrm{~cm}$ distance for $1 \mathrm{~min}\left(144 \mathrm{mj} / \mathrm{cm}^{2}\right)$; a combination of $1.5 \%$ malic acid or $1.5 \%$ lactic acid with or without UV-C $\left(144 \mathrm{mj} / \mathrm{cm}^{2}\right)$, and $50 \%$ ethanol combined with UV-C $\left(144 \mathrm{mj} / \mathrm{cm}^{2}\right)$. The combined treatments were tested on cut vegetables (dipping and spraying) and intact vegetables (spraying) (Figure 1B). After treatment, the cut vegetables or the peels $(\sim 10 \mathrm{~g})$ from intact vegetables separated with a sterile peeler were immediately transferred to a stomacher bag containing $9 \times$ volume of BD Difco ${ }^{\mathrm{TM}} \mathrm{D} / \mathrm{E}$ (Dey-Engley) neutralizing broth and homogenized with a BagMixer ${ }^{\circledR} 400$ (Interscience, St. Nom, France) stomacher for $1 \mathrm{~min}$.

\subsection{Bacterial Enumeration}

The homogenized filtered mixture was serial diluted with $9 \mathrm{~mL}$ of $0.1 \%$ peptone water (PW; Oxoid). One hundred microliters of the serial diluted samples were spread on PALCAM agar base (Oxoid) plates and incubated at $37^{\circ} \mathrm{C}$. After incubation for $24 \mathrm{~h}$, the bacterial colonies were enumerated.

\subsection{Statistical Analysis}

All the treatments were repeated three times (biological replicates) with triplicates (technical replicates). Each biological replicate involving inoculated radish, melon, and carrot samples consisted of three samples (cut vegetable for individual treatments and intact vegetable for combination treatments) exposed to the same treatment conditions. Means and standard deviations were evaluated using the Microsoft Excel software (Microsoft Corporation, Redmond, WA, USA). Bacterial enumeration (CFU/g of sample) were analyzed after log transformation. The SigmaPlot software version 12.5 (Systat Software Inc., Chicago, IL, USA) was used to perform t-tests to assess the significant variation between the treated cut/intact vegetable samples and untreated control samples. Statistics by $t$-test are represented as ${ }^{*} p<0.01{ }^{* *} p<0.001$, and ${ }^{* * *} p<0.0001$ [60].

\section{Results}

\subsection{Efficiency of Organic Acids against Listeria monocytogenes in Fresh Produce}

The populations of L. monocytogenes in untreated control radish, melon, and carrot cut samples were $7.69 \pm 0.12,6.18 \pm 0.02$, and $6.22 \pm 0.02 \log$ CFU/g, respectively. Malic acid and lactic acid of $3 \%$ were most effective against L. monocytogenes in radish $(5.53 \pm 0.18$ and $4.53 \pm 0.04 \log \mathrm{CFU} / \mathrm{g})$ and melon $(2.37 \pm 0.07$ and $1.19 \pm 0.39 \log \mathrm{CFU} / \mathrm{g})$ samples compared to the untreated radish and melon control samples. The reduction in L. monocytogenes by $3 \%$ malic acid and 3\% lactic acid in radish samples were $>2 \log \mathrm{CFU} / \mathrm{g}$ and in melons were $>4 \log$ CFU/g (Figure 2). In the case of the carrot samples, a $1 \log$ CFU/g reduction ( $5.15 \pm 0.05 \log \mathrm{CFU} / \mathrm{g})$ in the population of L. monocytogenes was observed between the control and treated samples. 

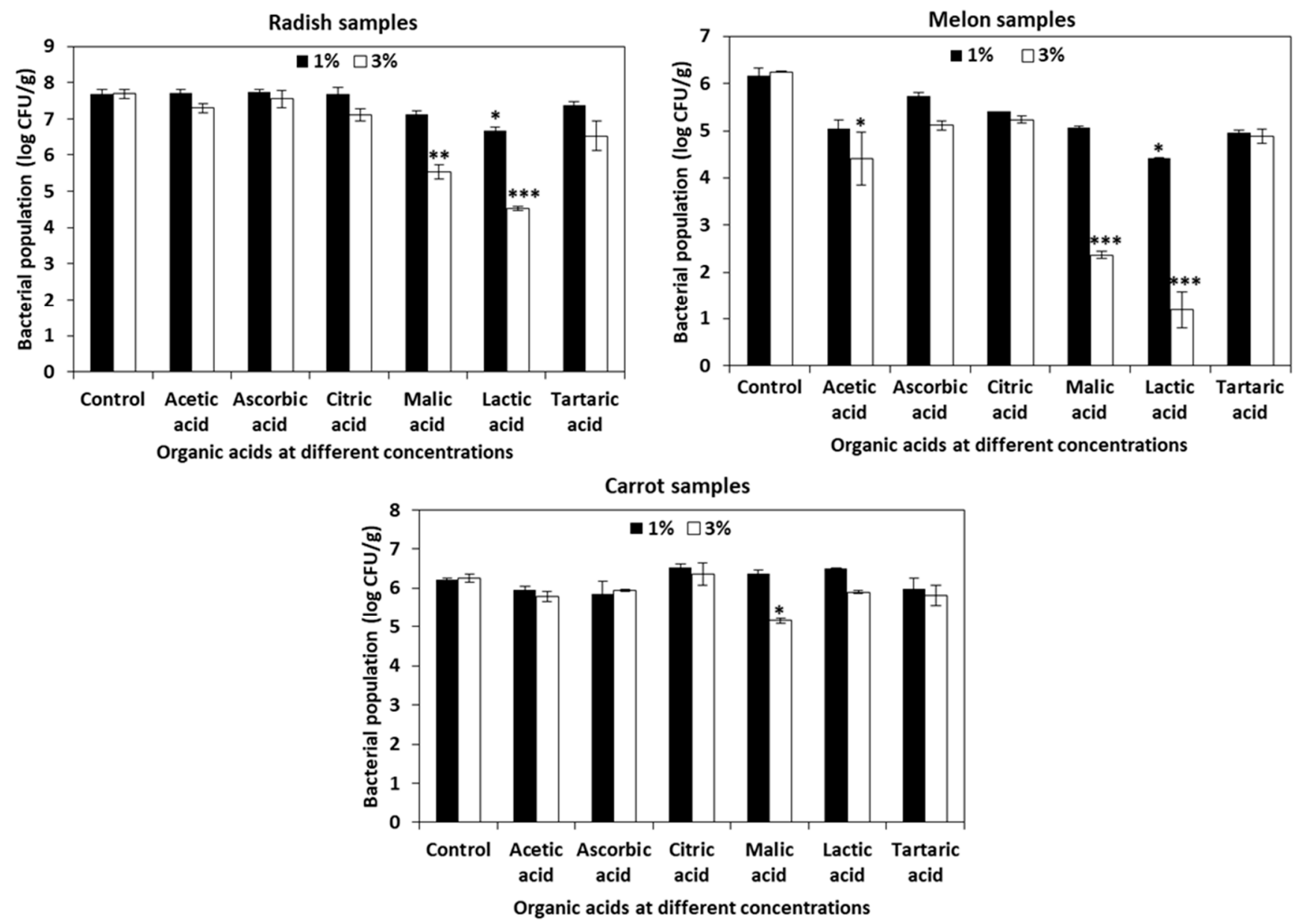

Figure 2. Efficiency of organic acids against L. monocytogenes in cut vegetable samples of radish, melon, and carrot. The organic acids acetic acid, ascorbic acid, citric acid, malic acid, lactic acid, and tartaric acid at a concentration of $1 \%$ and $3 \%$ were applied on radish, melon, and carrot samples and their effectiveness against L. monocytogenes was analyzed. The data obtained are the means \pm SD from three independent experiments with triplicates. Statistical analysis ( $t$-test) was conducted using SigmaPlot. For t-test analysis, the values of organic acids-treated cut vegetable samples were compared with those of the untreated cut vegetable control samples. An asterisk indicates significant differences compared with the control $\left({ }^{*} p<0.01,{ }^{* *} p<0.001,{ }^{* * *} p<0.001\right)$.

\subsection{Efficiency of UV-C against Listeria monocytogenes in Fresh Produce}

UV-C at intensities of $4.7 \mathrm{~mW} / \mathrm{cm}^{2}$ and $2.4 \mathrm{~mW} / \mathrm{cm}^{2}$ were effective ( $>2 \log$ CFU/g reduction) in radish samples at $1 \mathrm{~min}(5.72 \pm 0.23 \log \mathrm{CFU} / \mathrm{g})$ and $5 \mathrm{~min}(5.77 \pm 0.11 \log \mathrm{CFU} / \mathrm{g})$, respectively. In melon samples, UV-C radiation of $2.4 \mathrm{~mW} / \mathrm{cm}^{2}$ for $15 \mathrm{~min}(4.85 \pm 0.21 \mathrm{log} \mathrm{CFU} / \mathrm{g})$ and $30 \mathrm{~min}(3.03 \pm 0.48 \log \mathrm{CFU} / \mathrm{g})$ exposure were the most effective ( $>2$ and $4 \mathrm{log}$ CFU/g reduction) in reducing $L$. monocytogenes. In the case of the carrot samples, exposure of $4.7 \mathrm{~mW} / \mathrm{cm}^{2} \mathrm{UV}-\mathrm{C}$ for $1 \mathrm{~min}(6.61 \pm 0.22 \log \mathrm{CFU} / \mathrm{g})$ showed a $1 \log \mathrm{CFU} / \mathrm{g}$ reduction in L. monocytogenes. The levels of L. monocytogenes in the untreated control radish, melon, and carrot samples were $7.82 \pm 0.12,7.48 \pm 0.10$, and $7.71 \pm 0.07 \log C F U / g$, respectively (Figure 3). 

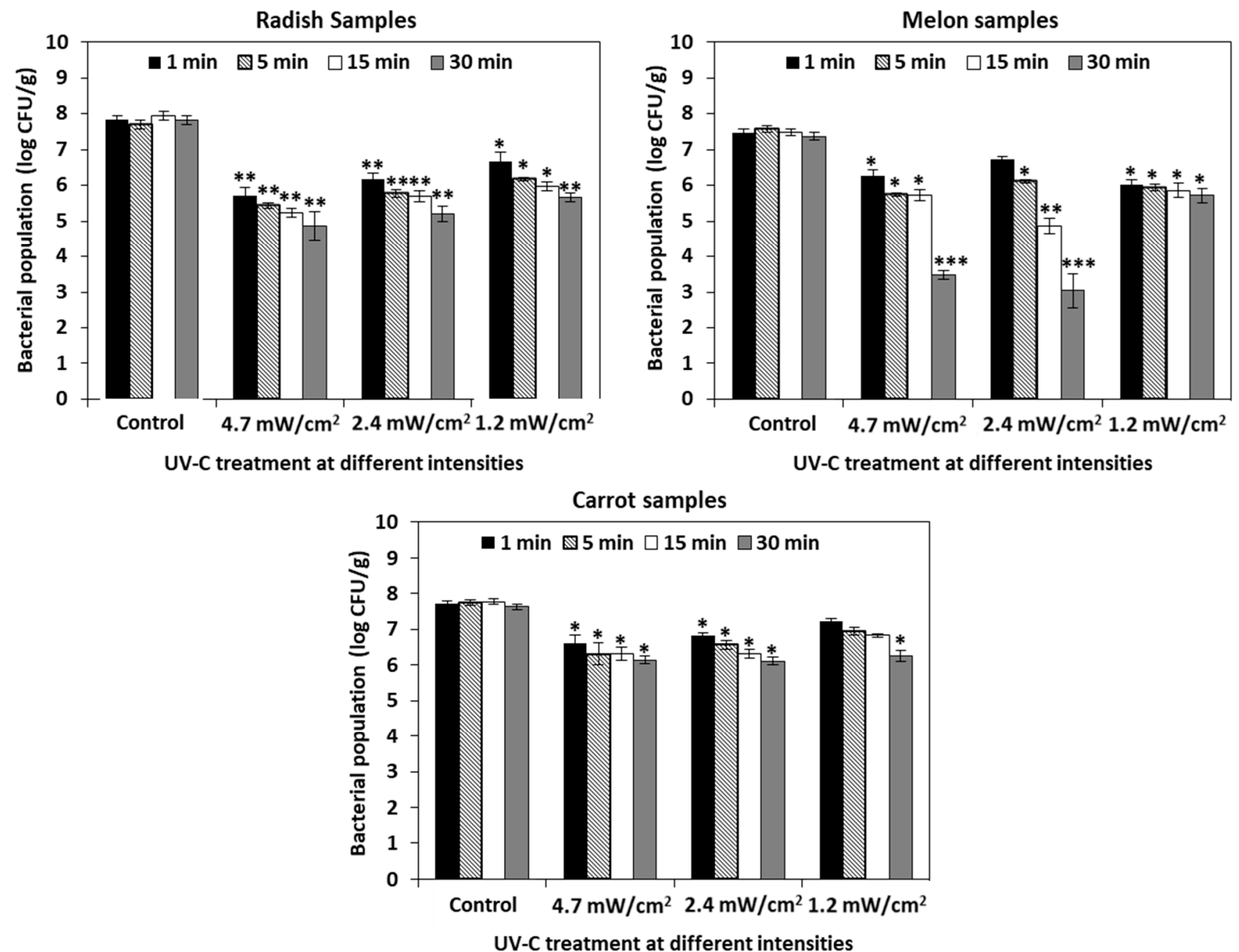

Figure 3. Effectiveness of UV-C against Listeria monocytogenes in cut vegetable samples of radish, melon, and carrot. Radish, melon, and carrot samples were exposed to UV-C radiation at distance of 15, 30, and $45 \mathrm{~cm}$ for 1, 5, 15, and 30 min and the population of L. monocytogenes was enumerated on PALCAM agar plates. The data obtained are the means $\pm \mathrm{SD}$ from three independent experiments with triplicates. Statistical analysis (t-test) was conducted using SigmaPlot. For t-test analysis, the values of the UV-C-treated cut vegetable samples were compared with that of the untreated cut vegetable control samples. An asterisk indicates significant differences compared with the control samples $\left({ }^{*} p<0.01,{ }^{* *} p<0.001,{ }^{* * *} p<0.001\right)$.

\subsection{Efficiency of Ethanol against Listeria monocytogenes in Fresh Produce}

The populations of L. monocytogenes in untreated control radish, melon, and carrot samples were $8.10 \pm 0.09,6.63 \pm 0.06$, and $7.10 \pm 0.06 \log C F U / g$, respectively. Ethanol at concentrations of $50 \%$ and $70 \%$ for $1 \mathrm{~min}(4.23 \pm 0.14$ and $4.10 \pm 0.83 \log \mathrm{CFU} / \mathrm{g})$ and $3 \mathrm{~min}(4.20 \pm 0.06$ and $2.97 \pm 0.25 \log \mathrm{CFU} / \mathrm{g})$ were most effective $(>3.8 \log \mathrm{CFU} / \mathrm{g}$ reduction) in radish samples. In the case of the melon samples, $50 \%$ ethanol for $3 \mathrm{~min}$ $(4.21 \pm 0.28 \log \mathrm{CFU} / \mathrm{g})$ and $70 \%$ ethanol for $1 \mathrm{~min}(4.06 \pm 0.04 \log \mathrm{CFU} / \mathrm{g})$ and $3 \mathrm{~min}$ ( $3.60 \pm 0.89 \log \mathrm{CFU} / \mathrm{g}$ ) were effective (>2.5 $\log \mathrm{CFU} / \mathrm{g}$ reduction). L. monocytogenes was significantly reduced (1.3 $\log \mathrm{CFU} / \mathrm{g}$ reduction) in carrots when $50 \%$ ethanol was applied for $3 \mathrm{~min}(5.80 \pm 0.47 \log \mathrm{CFU} / \mathrm{g})$ (Figure 4). 

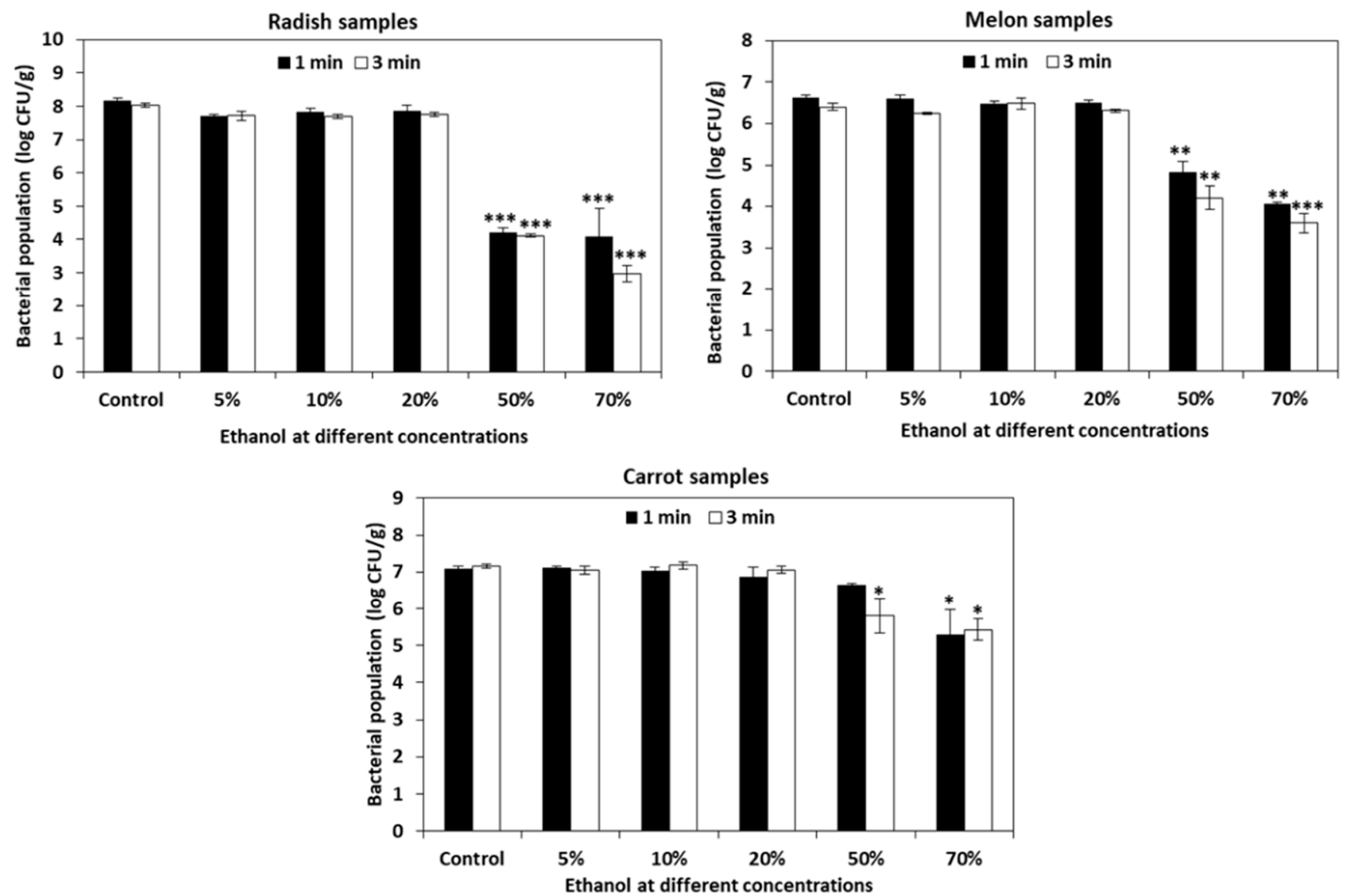

Figure 4. Efficiency of ethanol against Listeria monocytogenes in cut vegetable samples of radish, melon, and carrot. Ethanol at different concentrations $(5 \%, 10 \%, 20 \%, 50 \%$, and $70 \%$ ) was applied on radish, melon, and carrot samples for 1 and 3 min and its effectiveness against $L$. monocytogenes was analyzed. The data obtained are the means \pm SD from three independent experiments with triplicates. Statistical analysis (t-test) was conducted using SigmaPlot. For $t$-test analysis, the values of ethanol-treated cut vegetable samples were compared with those of the untreated cut vegetable control samples. An asterisk indicates significant differences compared with the control $\left({ }^{*} p<0.01,{ }^{* *} p<0.001,{ }^{* * *} p<0.001\right)$.

\subsection{Combination Efficiency of Organic Acids, UV, and Ethanol against Listeria monocytogenes on Cut and Intact Vegetables}

The organic acids, malic acid or lactic acid, at $3 \%$ concentrations combined with UV$\mathrm{C}$ at $30 \mathrm{~cm}$ distance for $1 \mathrm{~min}\left(144 \mathrm{mj} / \mathrm{cm}^{2}\right)$; a combination of $1.5 \%$ malic acid or $1.5 \%$ lactic acid with or without UV-C $\left(144 \mathrm{mj} / \mathrm{cm}^{2}\right)$, and $50 \%$ ethanol combined with UV-C $\left(144 \mathrm{mj} / \mathrm{cm}^{2}\right)$ were tested for their efficiency against L. monocytogenes in cut vegetable samples of radish, melon, and carrot. The treatments were applied to cut vegetables by the dipping method. The densities of $L$. monocytogenes inoculated cut vegetables without dipping treatment in control radish, melon, and carrot samples were $7.79 \pm 0.04,7.67 \pm 0.07$, and $7.36 \pm 0.05 \log \mathrm{CFU} / \mathrm{g}$, respectively. Combinations of $1.5 \%$ malic acid $+1.5 \%$ lactic acid + UV-C $30 \mathrm{~cm} / 1 \mathrm{~min}\left(144 \mathrm{mj} / \mathrm{cm}^{2}\right)$ showed $>4 \log \mathrm{CFU} / \mathrm{g}$ reduction in radish, melon, and carrot samples. Malic acid $(3 \%)+\mathrm{UV}-\mathrm{C}\left(144 \mathrm{mj} / \mathrm{cm}^{2}\right)$ reduced $>5 \log \mathrm{CFU} / \mathrm{g}$ in radish and melon samples while $>4 \log \mathrm{CFU} / \mathrm{g}$ reduction was observed in carrot samples. Lactic acid $(3 \%)+\mathrm{UV}-\mathrm{C}\left(144 \mathrm{mj} / \mathrm{cm}^{2}\right)$ significantly reduced L. monocytogenes in radish (>4.94 $\log \mathrm{CFU} / \mathrm{g}$ ), melon (>5.67 log CFU/g), and carrot (>2.4 log CFU/g) samples. Ethanol $(50 \%)+$ UV-C $\left(144 \mathrm{mj} / \mathrm{cm}^{2}\right)$ treatment by dipping method effectively reduced L. monocytogenes by $>2.07 \log \mathrm{CFU} / \mathrm{g}$ in radish, $>4.67 \mathrm{log} \mathrm{CFU} / \mathrm{g}$ in melon, and $>4.34 \log \mathrm{CFU} / \mathrm{g}$ in carrot samples (Figure 5). 

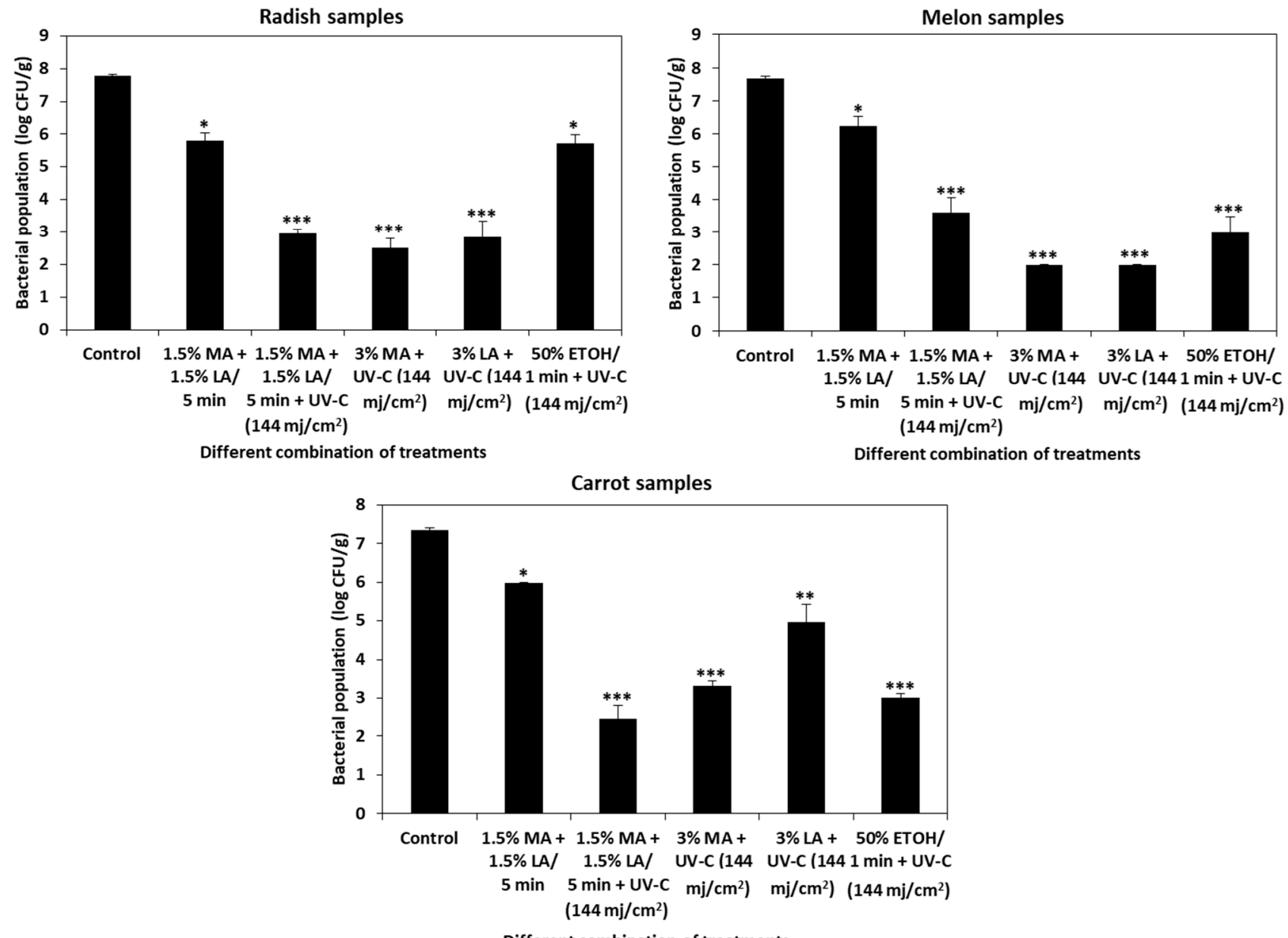

Figure 5. Combination of organic acids, UV, and ethanol (dipping) in cut vegetables. The effectiveness of dipping of cut vegetables in 1.5\% malic acid + 1.5\% lactic acid + UV-C $\left(144 \mathrm{mj} / \mathrm{cm}^{2}\right), 3 \%$ malic acid + UV-C $\left(144 \mathrm{mj} / \mathrm{cm}^{2}\right), 3 \% \mathrm{lactic}$ acid + UV-C $\left(144 \mathrm{mj} / \mathrm{cm}^{2}\right)$, and 50\% ethanol + UV-C $\left(144 \mathrm{mj} / \mathrm{cm}^{2}\right)$ was tested for its antilisterial activity in radish, melon, and carrot samples. The data obtained are the means \pm SD from three independent experiments with triplicates. Statistical analysis ( $t$-test) was conducted using SigmaPlot. For t-test analysis, the values of the dip-treated cut vegetable samples were compared with those of the untreated cut vegetable control samples. An asterisk indicates significant differences compared with the control $\left({ }^{*} p<0.01,{ }^{* *} p<0.001,{ }^{* * *} p<0.001\right)$.

The dipping treatment of cut vegetables in either 3\% malic acid, 3\% lactic acid, or $50 \%$ ethanol along with UV-C $\left(144 \mathrm{mj} / \mathrm{cm}^{2}\right)$ was highly efficient against L. monocytogenes. However, applying the dipping method to cut vegetables on a commercial scale is impracticable. Hence, we employed a spraying method on intact vegetables to analyze the efficiency of combined treatments (Figure 1 ). In radish samples, 3\% malic acid + UV-C $\left(144 \mathrm{mj} / \mathrm{cm}^{2}\right)$ significantly reduced $(>4 \log \mathrm{CFU} / \mathrm{g})$ the population of L. monocytogenes (1.44 \pm 0.5$)$ compared to the control sample (5.14 $\pm 0.09 \log$ CFU $/ g)$ (Figure 6). In the case of melon samples, 3\% lactic acid $+144 \mathrm{mj} / \mathrm{cm}^{2} \mathrm{UV}-\mathrm{C}(2.30 \pm 0.75 \mathrm{log}$ CFU/g) and 50\% ethanol $+144 \mathrm{mj} / \mathrm{cm}^{2} \mathrm{UV}-\mathrm{C}(2.30 \pm 0.01 \mathrm{log} \mathrm{CFU} / \mathrm{g})$ were effective against L. monocytogenes. Lactic acid $(3 \%)+\mathrm{UV}-\mathrm{C}\left(144 \mathrm{mj} / \mathrm{cm}^{2}\right)$ showed a slight reduction $(4.48 \pm 0.25 \log \mathrm{CFU} / \mathrm{g})$ in carrot samples. 

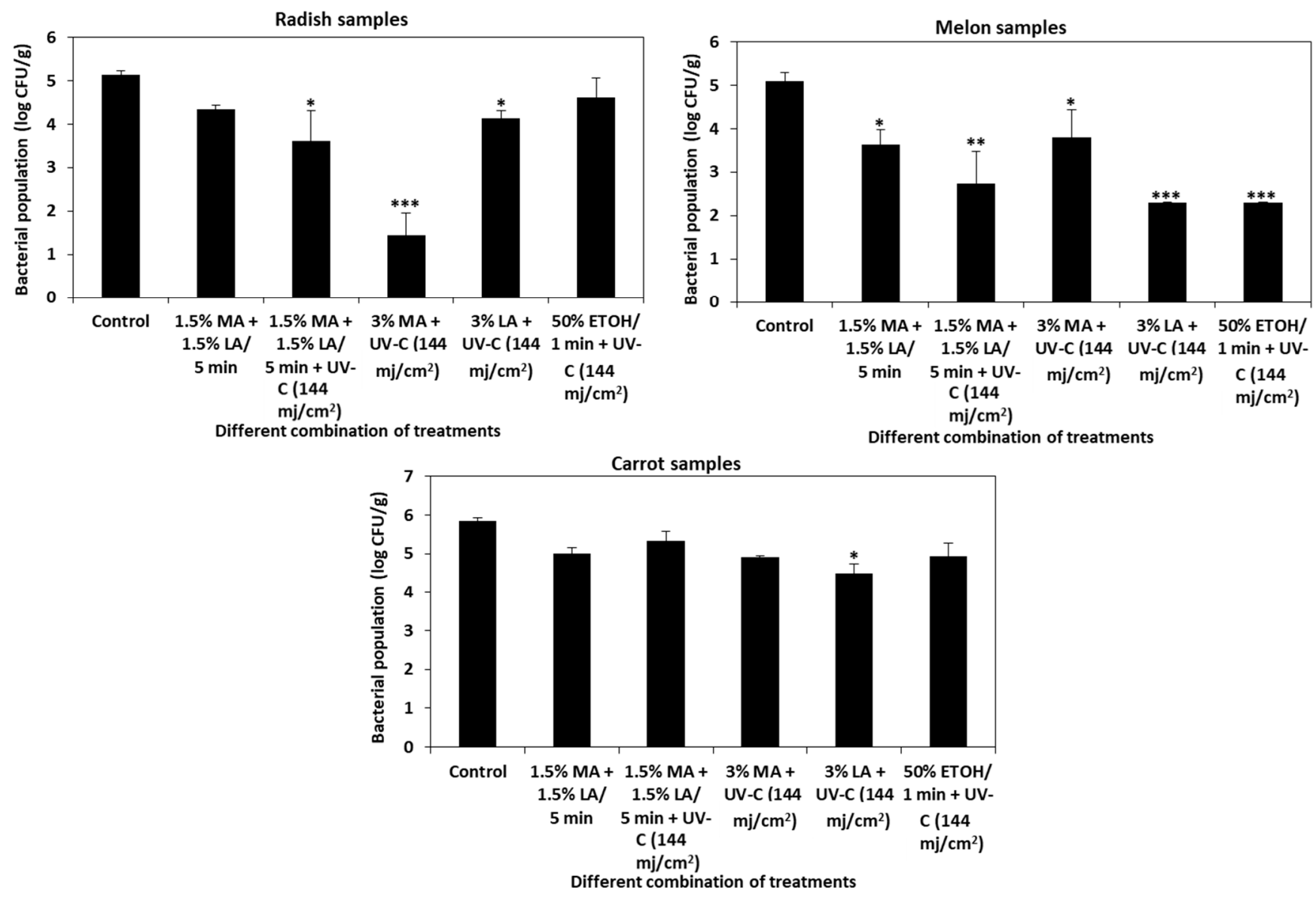

Figure 6. Combination of organic acids, UV-C, and ethanol (spraying) on intact vegetables. The effectiveness of spraying $1.5 \%$ malic acid $+1.5 \%$ lactic acid + UV-C $\left(144 \mathrm{mj} / \mathrm{cm}^{2}\right), 3 \%$ malic acid $+\mathrm{UV}-\mathrm{C}\left(144 \mathrm{mj} / \mathrm{cm}^{2}\right), 3 \%$ lactic acid $+\mathrm{UV}-\mathrm{C}$ $\left(144 \mathrm{mj} / \mathrm{cm}^{2}\right)$, and $50 \%$ ethanol $+\mathrm{UV}-\mathrm{C}\left(144 \mathrm{mj} / \mathrm{cm}^{2}\right)$ on intact vegetables was analyzed for its antilisterial activity in radish, melon, and carrot samples. The data obtained are the means \pm SD from three independent experiments with triplicates. Statistical analysis (t-test) was conducted using SigmaPlot. For t-test analysis, the values of the spray-treated intact vegetable samples were compared with those of the untreated cut vegetable control samples. An asterisk indicates significant differences compared with the control $\left({ }^{*} p<0.01,{ }^{* *} p<0.001,{ }^{* * *} p<0.001\right)$.

\section{Discussion}

The attachment, growth, and survival of L. monocytogenes on the surfaces of vegetables vary between crops based on their surface characteristics [61], storage time, and temperature where the crop is produced and processed [19]. The antimicrobial effects of organic acids, UV-C, and ethanol on lettuce, apples, and other vegetables have been documented previously $[3,28,57,58]$. However, studies regarding the individual and combinational efficiency of these treatments on other vegetables during produce washing is still limited. This is the first study to investigate the individual and combined efficiency of organic acids, $\mathrm{UV}-\mathrm{C}$, and ethanol to reduce L. monocytogenes contamination on carrot, radish, and melon.

Organic acids are considered as safe and potential alternatives for chlorine based chemical sanitizers owing to their preservative and antioxidant properties and most importantly, their natural origin as well as low production cost [28]. Moreover, the disinfection efficiency of organic acids were proved to be on par or better than some chlorine based chemical sanitizers [62]. In our study, among all the other organic acids (acetic acid, ascorbic acid, citric acid, and tartaric acid), malic acid and lactic acid at a concentration of $3 \%$ were more effective in reducing L. monocytogenes population in radish ( 2 and $3 \log C F U / g$ reduction) and melon (4 and $5 \log \mathrm{CFU} / \mathrm{g}$ reduction) samples (Figure 2). In a similar study on enoki mushrooms, Kim et al. (2020) observed 3 log reductions in L. monocytogenes when treated with 3\% lactic acid and malic acid for $10 \mathrm{~min}$ [63]. Concha-Meyer et al. (2017) observed a 
complete inhibition of L. monocytogenes in solutions of tryptic soy broth with yeast extract (TSB-YE) containing malic acid and lactic acid [64].

This disinfection ability of malic acid and lactic acid could be due to their smaller undissociated molecular sizes (134.09 Da and 90.08 Da, respectively), which may easily diffuse through the microbial cell membrane and change their internal $\mathrm{pH}$ [65]. This change in $\mathrm{pH}$ causes deformation and obstruction to intracellular activities and eventually cell death [55]. Their counterparts ascorbic (176.12 Da), citric (192.13 Da), and tartaric (150.09 Da) acids did not effectively reduce L. monocytogenes possibly due to their larger undissociated molecular sizes [66]. As a case in point, transmission electron microscopy studies by Raybaudi-Massilia et al. (2009) and Yoon et al. (2021) revealed that malic acid caused damage in the cytoplasm of L. monocytogenes, S. enteritidis and E. coli without altering the structure of their cell membranes $[67,68]$. Though the undissociated molecular size of acetic acid $(60 \mathrm{Da})$ is smaller than the malic acid and lactic acid, its inefficiency in killing L. monocytogenes is yet unknown. In addition to the smaller molecular size, the acidity of malic acid was shown to be less affected by the organic substrates released from the crops during treatments making them more effective in reducing L. monocytogenes than other organic acids [68].

The bactericidal efficiency of UV-C light on fruit surfaces differs based on the surface characteristics. Fruit surfaces with rough texture help pathogens to attach firmly $[69,70]$ to the fruits making them difficult to access and remove during sanitizing treatments [71,72]. Moreover, UV-C light cannot penetrate through the bumps and cracks on rough surfaces. Silva et al. (2003) demonstrated that UV light was not able to probe through the cracks and protuberance of low-density polyethylene film and effectively reduce Staphylococcus aureus and E. coli populations on them [73]. Adhikari et al. (2015) observed significant reduction in L. monocytogenes population on apple and pear fruits that have smoother surfaces compared to cantaloupe and strawberry that have rough surfaces by UV$\mathrm{C}$ light exposure [74]. Correspondingly, in our study, UV-C treatment significantly reduced L. monocytogenes on radish (2-log CFU/g reduction at a dosage of $\left.144 \mathrm{mj} / \mathrm{cm}^{2}\right)$ and melon (3-log CFU/g reduction at a dosage of $144 \mathrm{mj} / \mathrm{cm}^{2}$ ) samples (Figure 3), which have smooth surfaces while no significant reduction was observed on carrot surfaces with coarse texture. Since UV-C light may not be able to access through the surfaces of carrots efficiently as that of radish and melon samples, their effectiveness in inactivating L. monocytogenes was different between the samples.

Ethanol at a concentration of $50 \%$ and $70 \%$ effectively inactivated 2 to $4 \log \mathrm{CFU} / \mathrm{g}$ of L. monocytogenes in radish and melon samples in $3 \mathrm{~min}$ (Figure 4). Ethanol has been frequently used as a sanitizer in several clinical and microbiological labs for several years. However, its individual application on food products as a disinfectant is exceedingly rare. In many cases, ethanol was mostly combined with other sanitizers to use on food products. For instance, ethanol at a concentration of 30\% combined with $1 \%$ ascorbic acid effectively inactivated pathogens on fresh-cut apples [75] and fresh-cut lotus root [76]. In another study, $5 \%$ ethanol with low $\mathrm{pH}$ (3.0) combined with $50 \mathrm{mM}$ formate significantly reduced L. monocytogenes in $4 \mathrm{~min}$ [55]. Apart from inactivating the microbes, ethanol evaporates quickly without leaving any residue on the fruit surface making it a suitable candidate for sanitizing treatments.

UV-C treatment has limited efficiency in inactivating microbes on rough surfaces and the application of organic acids at low concentrations would be more preferable than higher concentrations. Based on the practical factors such as minimal processing time and low concentration, we speculated that combination of these treatments could increase the efficiency of sanitizers against $L$. monocytogenes on food products. Dipping of cut vegetables in either malic acid (1.5\%) + lactic acid (1.5\%), 3\% malic acid, 3\% lactic acid or 50\% ethanol along with UV-C $\left(144 \mathrm{mj} / \mathrm{cm}^{2}\right)$ significantly reduced L. monocytogenes in radish, melon, and carrot samples (Figure 5). However, applying the dipping method to cut or intact vegetables is not feasible in a commercial scale because cross contamination may occur between contaminated and noncontaminated fresh produce and a change in the $\mathrm{pH}$ of 
dipping solution due to release of naturally occurring organic acids from vegetables may hinder disinfection efficiency [77]. Hence, we employed a spraying method for analyzing the efficiency of combined treatments on cut and intact vegetables. Since no significant reduction in L. monocytogenes was observed on cut vegetables by the spraying method (data not shown), we tested the combined efficiency of the treatments on intact vegetables. Combined treatments of $3 \%$ malic acid with UV-C at a dosage of $144 \mathrm{mj} / \mathrm{cm}^{2}$ significantly reduced ( $>4 \log \mathrm{CFU} / \mathrm{g}$ reduction) L. monocytogenes in radish samples (Figure 6). Lactic acid at a concentration of $3 \%$ combined with UV-C $\left(144 \mathrm{mj} / \mathrm{cm}^{2}\right.$ dose $)$ or $50 \%$ ethanol with UV-C $\left(144 \mathrm{mj} / \mathrm{cm}^{2}\right)$ significantly reduced L. monocytogenes in melon ( $>2 \log \mathrm{CFU} / \mathrm{g}$ reduction) samples. Interestingly, a combination of $3 \%$ lactic acid with UV-C $\left(144 \mathrm{mj} / \mathrm{cm}^{2}\right)$ reduced L. monocytogenes up to $1.5 \mathrm{log} \mathrm{CFU} / \mathrm{g}$ in carrot samples where individual application of these treatments did not significantly inactivate L. monocytogenes.

According to the results of our experiment, spraying 3\% lactic acid or $50 \%$ ethanol during washing followed by UV-C $\left(144 \mathrm{mj} / \mathrm{cm}^{2}\right)$ application can reduce the risk of L. monocytogenes. However, there are some limitations in this study to using these strategies on an industrial scale. For instance, the organic acids lactic acid or malic acid can assist in reducing pathogenic contamination but cannot completely inactivate or kill the pathogens in contaminated fresh produce $[48,77]$. Although the UV-C and ethanol treatments were effective in reducing L. monocytogenes in this study, application of these methods in an industrial setting is not common due to complex management, additional cost, technical issues, and other practical factors [78]. In addition, all the experiments in this study were performed in a laboratory setting at room temperature while most of the fresh-cut processing in industries is carried out at temperatures below $10^{\circ} \mathrm{C}$.

Taken together, the results of this study reveal that sanitizing treatments developed against microbes for one food product are often less effective for another food product. This could be due to the difference in the characteristics of the food surfaces, which plays a vital role in the effectiveness of the sanitizers [77]. Several other attributes including exposure time, contact angle, surface topology, hydrophobicity, morphology, and cell wall components of the fruit surfaces also influence the antimicrobial efficiency of the sanitizers [73,79]. Hence, a better understanding of the surface characteristics of each agricultural product can help to develop an efficient customized sanitizing treatment to prevent pathogen contamination during the washing step in the production process.

Author Contributions: Conceptualization, N.R. and S.-Y.C.; methodology, N.R., H.-B.C., H.-J.C.; software, I.H.; validation, N.R., S.-Y.C., J.-E.H. and S.-R.K.; formal analysis, N.R.; investigation, N.R.; resources, S.-Y.C., S.-R.K.; data curation, N.R.; writing-original draft preparation, N.R.; writingreview and editing, N.R., S.-Y.C., I.H., S.-R.K.; visualization, N.R.; supervision, S.-Y.C.; project administration, S.-Y.C., S.-R.K.; funding acquisition, S.-Y.C. All authors have read and agreed to the published version of the manuscript.

Funding: This research was funded by the National Institution of Agricultural Science, Rural Development Administration, Republic of Korea. Grant number: PJ01426401.

Acknowledgments: I would like to thank Vimal Raj Mani, Bala Murali Krishna Vasamsetti, and my lab members Park Dae-Su, Kim Eun-Sun, Joo Hye-Young, Jeong Do-Yeong, Lee Su-Bin, Jang Youn-Jung, and Kim Min-Hae for their technical support.

Conflicts of Interest: The authors declare no conflict of interest. The funders had no role in the design of the study; in the collection, analyses, or interpretation of data; in the writing of the manuscript, or in the decision to publish the results.

\section{References}

1. Morey, A.; McKee, S.R.; Dickson, J.S.; Singh, M. Efficacy of ultraviolet light exposure against survival of Listeria monocytogenes on conveyor belts. Foodborne Pathog. Dis. 2010, 7, 737-740. [CrossRef]

2. Centers for Disease Control and Prevention. Listeria (Listeriosis). Available online: https://www.cdc.gov/listeria/index.html (accessed on 14 May 2021). 
3. Dev Kumar, G.; Williams, R.C.; Sumner, S.S.; Eifert, J.D. Effect of ozone and ultraviolet light on Listeria monocytogenes populations in fresh and spent chill brines. Food Control 2016, 59, 172-177. [CrossRef]

4. The United States Food and Drug Administration. Outbreak Investigation of Listeria monocytogenes: Enoki Mushrooms (March 2020). Available online: https://www.fda.gov/food/outbreaks-foodborne-illness/outbreak-investigation-listeriamonocytogenes-enoki-mushrooms-march-2020 (accessed on 9 June 2020).

5. Centers for Disease Control and Prevention. Multistate Outbreak of Listeriosis Linked to Commercially Produced, Prepackaged Caramel Apples Made from Bidart Bros. Apples. Available online: https://www.cdc.gov/listeria/outbreaks/caramel-apples-12 -14/index.html (accessed on 12 February 2015).

6. Centers for Disease Control and Prevention. Multistate Outbreak of Listeriosis Linked to Frozen Vegetables. Available online: https:/ / www.cdc.gov/listeria/outbreaks/frozen-vegetables-05-16/index.html (accessed on 15 July 2016).

7. Centers for Disease Control and Prevention. Multistate Outbreak of Salmonella Typhimurium and Salmonella Newport Infections Linked to Cantaloupe. Available online: https:/ / www.cdc.gov/salmonella/typhimurium-cantaloupe-08-12/index. html (accessed on 5 October 2012).

8. Walsh, K.A.; Bennett, S.D.; Mahovic, M.; Gould, L.H. Outbreaks associated with cantaloupe, watermelon, and honeydew in the United States, 1973-2011. Foodborne Pathog. Dis. 2014, 11, 945-952. [CrossRef]

9. Ding, T.; Iwahori, J.; Kasuga, F.; Wang, J.; Forghani, F.; Park, M.-S.; Oh, D.-H. Risk assessment for Listeria monocytogenes on lettuce from farm to table in Korea. Food Control 2013, 30, 190-199. [CrossRef]

10. Johannessen, G.S.; Loncarevic, S.; Kruse, H.J. Bacteriological analysis of fresh produce in Norway. Int. J. Food Microbiol. 2002, 77, 199-204. [CrossRef]

11. Ponniah, J.; Robin, T.; Paie, M.S.; Radu, S.; Ghazali, F.M.; Kqueen, C.Y.; Nishibuchi, M.; Nakaguchi, Y.; Malakar, P.K. Listeria monocytogenes in raw salad vegetables sold at retail level in Malaysia. Food Control. 2010, 21, 774-778. [CrossRef]

12. Sy, K.V.; Murray, M.B.; Harrison, M.D.; Beuchat, L.R. Evaluation of gaseous chlorine dioxide as a sanitizer for killing Salmonella, Escherichia coli O157: H7, Listeria monocytogenes, and yeasts and molds on fresh and fresh-cut produce. J. Food Prot. 2005, 68, 1176-1187. [CrossRef]

13. Ruiz-Cruz, S.; Acedo-Félix, E.; Díaz-Cinco, M.; Islas-Osuna, M.A.; González-Aguilar, G.A. Efficacy of sanitizers in reducing Escherichia coli O157: H7, Salmonella spp. and Listeria monocytogenes populations on fresh-cut carrots. Food Control. 2007, 18, 1383-1390. [CrossRef]

14. Petran, R.; Zottou, E.; Gravani, R.J. Incidence of Listeria monocytogenes in market samples of fresh and frozen vegetables. J. Food Sci. 1988, 53, 1238-1240. [CrossRef]

15. Heisick, J.; Wagner, D.; Nierman, M.; Peeler, J.T. Listeria spp. found on fresh market produce. Appl. Environ. Microbiol. 1989, 55, 1925-1927. [CrossRef]

16. Aureli, P.; Fiorucci, G.C.; Caroli, D.; Marchiaro, G.; Novara, O.; Leone, L.; Salmaso, S.J. An outbreak of febrile gastroenteritis associated with corn contaminated by Listeria monocytogenes. N. Engl. J. Med. 2000, 342, 1236-1241. [CrossRef]

17. Scallan, E.; Hoekstra, R.M.; Angulo, F.J.; Tauxe, R.V.; Widdowson, M.-A.; Roy, S.L.; Jones, J.L.; Griffin, P.M. Foodborne illness acquired in the United States-Major pathogens. Emerg. Infect. Dis. 2011, 17, 7. [CrossRef] [PubMed]

18. Porto, E.; Eiroa, M.N. Occurrence of Listeria monocytogenes in vegetables. Dairy Food Environ. Sanit. 2001, 21, $282-286$.

19. Gorski, L.; Palumbo, J.D.; Mandrell, R.E. Attachment of Listeria monocytogenes to radish tissue is dependent upon temperature and flagellar motility. Appl. Environ. Microbiol. 2003, 69, 258-266. [CrossRef] [PubMed]

20. Zhuang, H.; Barth, M.M.; Hankinson, T.R. Microbial safety, quality, and sensory aspects of fresh-cut fruits and vegetables. In Microbial Safety of Minimally Processed Foods; 2003; Volume 12, pp. 255-278. [CrossRef]

21. Jeyaletchumi, P.; Tunung, R.; Selina, P.M.; Chai, L.; Radu, S.; Farinazleen, M.; Cheah, Y.; Mitsuaki, N.; Yoshitsugu, N.; Kumar, M.P. Assessment of Listeria monocytogenes in salad vegetables through kitchen simulation study. J. Trop. Agric. Food Sci. 2012, 40, 55-62.

22. Jamali, H.; Paydar, M.; Looi, C.Y.; Wong, W.F. Prevalence of Listeria species and Listeria monocytogenes serotypes in ready mayonnaise salads and salad vegetables in Iran. Afr. J. Microbiol. Res. 2013, 7, 1903-1906.

23. Qadri, O.S.; Yousuf, B.; Srivastava, A.K. Fresh-cut fruits and vegetables: Critical factors influencing microbiology and novel approaches to prevent microbial risks-A review. Cogent Food Agric. 2015, 1, 1121606. [CrossRef]

24. Banach, J.L.; van Bokhorst-van de Veen, H.; van Overbeek, L.S.; van der Zouwen, P.S.; van der Fels-Klerx, H.J.; Groot, M.N.N. The efficacy of chemical sanitizers on the reduction of Salmonella typhimurium and Escherichia coli affected by bacterial cell history and water quality. Food Control 2017, 81, 137-146. [CrossRef]

25. Amrutha, B.; Sundar, K.; Shetty, P.H. Study on E. coli and Salmonella biofilms from fresh fruits and vegetables. J. Food Sci. Technol. 2017, 54, 1091-1097. [CrossRef] [PubMed]

26. Leneveu-Jenvrin, C.; Quentin, B.; Assemat, S.; Hoarau, M.; Meile, J.-C.; Remize, F. Changes of Quality of Minimally-Processed Pineapple (Ananas comosus, var. 'Queen Victoria') during Cold Storage: Fungi in the Leading Role. Microorganisms 2020, 8, 185. [CrossRef]

27. Gombas, D.; Luo, Y.; Brennan, J.; Shergill, G.; Petran, R.; Walsh, R.; Hau, H.; Khurana, K.; Zomorodi, B.; Rosen, J.; et al. Guidelines To Validate Control of Cross-Contamination during Washing of Fresh-Cut Leafy Vegetables. J. Food Prot. 2017, 80, 312-330. [CrossRef] [PubMed] 
28. Park, S.H.; Choi, M.R.; Park, J.W.; Park, K.H.; Chung, M.S.; Ryu, S.; Kang, D.H. Use of organic acids to inactivate Escherichia coli O157:H7, Salmonella typhimurium, and Listeria monocytogenes on organic fresh apples and lettuce. J. Food Sci. 2011, 76, M293-M298. [CrossRef]

29. Yoon, J.-H.; Bae, Y.-M.; Jung, S.-Y.; Cha, M.-H.; Ryu, K.; Park, K.-H.; Lee, S.-Y. Predictive modeling for the growth of Listeria monocytogenes and Salmonella typhimurium on fresh-cut cabbage at various temperatures. J. Korean Soc. Appl. Biol. Chem. 2014, 57, 631-638. [CrossRef]

30. Rodgers, S.L.; Cash, J.N.; Siddiq, M.; Ryser, E.T. A comparison of different chemical sanitizers for inactivating Escherichia coli O157: H7 and Listeria monocytogenes in solution and on apples, lettuce, strawberries, and cantaloupe. J. Food Prot. 2004, 67, 721-731. [CrossRef]

31. Singh, P.; Hung, Y.C.; Qi, H. Efficacy of peracetic acid in inactivating foodborne pathogens on fresh produce surface. J. Food Sci. 2018, 83, 432-439. [CrossRef]

32. Liang, Y.; Ji, L.; Chen, C.; Dong, C.; Wang, C. Effects of ozone treatment on the storage quality of post-harvest tomato. Int. J. Food Eng. 2018, 14, 7-8. [CrossRef]

33. Murray, K.; Moyer, P.; Wu, F.; Goyette, J.; Warriner, K. Inactivation of Listeria monocytogenes on and within apples destined for caramel apple production by using sequential forced air ozone gas followed by a continuous advanced oxidative process treatment. J. Food Prot. 2018, 81, 357-364. [CrossRef]

34. Sun, S.H.; Kim, S.J.; Kwak, S.J.; Yoon, K.S. Efficacy of sodium hypochlorite and acidified sodium chlorite in preventing browning and microbial growth on fresh-cut produce. Prev. Nutr. Food Sci. 2012, 17, 210-216. [CrossRef] [PubMed]

35. Haute, S.v.; Sampers, I.; Jacxsens, L.; Uyttendaele, M. Selection criteria for water disinfection techniques in agricultural practices. Crit. Rev. Food Sci. Nutr. 2015, 55, 1529-1551. [CrossRef] [PubMed]

36. Stratakos, A.C.; Linton, M.; Tessema, G.T.; Skjerdal, T.; Patterson, M.F.; Koidis, A. Effect of high pressure processing in combination with Weissella viridescens as a protective culture against Listeria monocytogenes in ready-to-eat salads of different $\mathrm{pH}$. Food Control. 2016, 61, 6-12. [CrossRef]

37. Donsì, F.; Marchese, E.; Maresca, P.; Pataro, G.; Vu, K.D.; Salmieri, S.; Lacroix, M.; Ferrari, G. Green beans preservation by combination of a modified chitosan based-coating containing nanoemulsion of mandarin essential oil with high pressure or pulsed light processing. Postharvest Biol. Technol. 2015, 106, 21-32. [CrossRef]

38. Huang, K.; Wrenn, S.; Tikekar, R.; Nitin, N. Efficacy of decontamination and a reduced risk of cross-contamination during ultrasound-assisted washing of fresh produce. J. Food Eng. 2018, 224, 95-104. [CrossRef]

39. Hashemi, S.M.B.; Abhari, K.; Mousavi Khaneghah, A. The combined effects of ultrasound and lactic acid in inactivating microorganisms on fresh radish (Raphanus raphanistrum subsp. sativus): Microbiological and quality changes. Food Sci. Nutr. 2020, $8,162-169$.

40. Ma, R.; Wang, G.; Tian, Y.; Wang, K.; Zhang, J.; Fang, J. Non-thermal plasma-activated water inactivation of food-borne pathogen on fresh produce. J. Hazard. Mater. 2015, 300, 643-651. [CrossRef]

41. Jiang, Y.; Sokorai, K.; Pyrgiotakis, G.; Demokritou, P.; Li, X.; Mukhopadhyay, S.; Jin, T.; Fan, X. Cold plasma-activated hydrogen peroxide aerosol inactivates Escherichia coli O157: H7, Salmonella Typhimurium, and Listeria innocua and maintains quality of grape tomato, spinach and cantaloupe. Int. J. Food Microbiol. 2017, 249, 53-60. [CrossRef]

42. Berardinelli, A.; Pasquali, F.; Cevoli, C.; Trevisani, M.; Ragni, L.; Mancusi, R.; Manfreda, G. Sanitisation of fresh-cut celery and radicchio by gas plasma treatments in water medium. Postharvest Biol. Technol. 2016, 111, 297-304. [CrossRef]

43. Butscher, D.; Van Loon, H.; Waskow, A.; von Rohr, P.R.; Schuppler, M. Plasma inactivation of microorganisms on sprout seeds in a dielectric barrier discharge. Int. J. Food Microbiol. 2016, 238, 222-232. [CrossRef]

44. Kamat, A.; Ghadge, N.; Ramamurthy, M.; Alur, M. Effect of low-dose irradiation on shelf life and microbiological safety of sliced carrot. J. Sci. Food Agric. 2005, 85, 2213-2219. [CrossRef]

45. Bhavya, M.L.; Umesh Hebbar, H. Pulsed light processing of foods for microbial safety. Food Qual. Saf. 2017, 1, 187-202. [CrossRef]

46. Pinto, L.; Baruzzi, F.; Ippolito, A. Recent advances to control spoilage microorganisms in washing water of fruits and vegetables: The use of electrolyzed water. In Proceedings of the III International Symposium on Postharvest Pathology: Using Science to Increase Food Availability ISHS Acta Hortic. 1144, Bari, Italy, 7-11 June 2015; pp. 379-384.

47. Chacha, J.S.; Zhang, L.; Ofoedu, C.E.; Suleiman, R.A.; Dotto, J.M.; Roobab, U.; Agunbiade, A.O.; Duguma, H.T.; Mkojera, B.T.; Hossaini, S.M. Revisiting Non-Thermal Food Processing and Preservation Methods-Action Mechanisms, Pros and Cons: A Technological Update (2016-2021). Foods 2021, 10, 1430. [CrossRef]

48. Coban, H.B. Organic acids as antimicrobial food agents: Applications and microbial productions. Bioprocess Biosyst. Eng. 2020, 43, 569-591. [CrossRef]

49. Warnecke, T.; Gill, R.T. Organic acid toxicity, tolerance, and production in Escherichia coli biorefining applications. Microb. Cell Factories 2005, 4, 25. [CrossRef]

50. Yasothai, R.; Giriprasad, R. Weak organic acids in food technology. Int. J. Environ. Sci. Technol. 2015, 4, 164-166.

51. Guerrero-Beltr·n, J.A.; Barbosa-C.novas, G.V. Advantages and limitations on processing foods by UV light. Food Sci. Technol. Int. 2004, 10, 137-147. [CrossRef]

52. Begum, M.; Hocking, A.D.; Miskelly, D. Inactivation of food spoilage fungi by ultra violet (UVC) irradiation. Int. J. Food Microbiol. 2009, 129, 74-77. [CrossRef] [PubMed] 
53. Eischeid, A.C.; Linden, K.G. Efficiency of pyrimidine dimer formation in Escherichia coli across UV wavelengths. J. Appl. Microbiol. 2007, 103, 1650-1656. [CrossRef] [PubMed]

54. Dao, T.; Dantigny, P. Control of food spoilage fungi by ethanol. Food Control 2011, 22, 360-368. [CrossRef]

55. Barker, C.; Park, S.F. Sensitization of Listeria monocytogenes to low pH, organic acids, and osmotic stress by ethanol. Appl. Environ. Microbiol. 2001, 67, 1594-1600. [CrossRef] [PubMed]

56. Sigua, G. Comparative efficacies of various sanitizers used in foodservice establishments. Ph.D. Thesis, Ohio State University, Columbus, OH, USA, 2009; pp. 5-16.

57. Chun, H.-H.; Kim, J.-Y.; Song, K.B. Inactivation of foodborne pathogens in ready-to-eat salad using UV-C irradiation. Food Sci. Biotechnol. 2010, 19, 547-551. [CrossRef]

58. Karyotis, D.; Skandamis, P. Control of Listeria monocytogenes by applying ethanol-based antimicrobial edible films on ham slices and microwave-reheated frankfurters. Food Microbiol. 2015, 54. [CrossRef]

59. Goodwin, J.F. Quantification of serum inorganic phosphorus, phosphatase, and urinary phosphate without preliminary treatment. Clin. Chem. 1970, 16, 776-780. [CrossRef] [PubMed]

60. Mani, V.; Reddy, C.S.; Lee, S.K.; Park, S.; Ko, H.R.; Kim, D.G.; Hahn, B.S. Chitin biosynthesis inhibition of Meloidogyne incognita by RNAi-mediated gene silencing increases resistance to transgenic tobacco plants. Int. J. Mol. Sci. 2020, 21, 6626. [CrossRef] [PubMed]

61. Marik, C.M.; Zuchel, J.; Schaffner, D.W.; Strawn, L.K. Growth and survival of Listeria monocytogenes on intact fruit and vegetable surfaces during postharvest handling: A systematic literature review. J. Food Prot. 2019, 83, 108-128. [CrossRef] [PubMed]

62. Akbas, M.; Ölmez, H. Inactivation of Escherichia coli and Listeria monocytogenes on iceberg lettuce by dip wash treatments with organic acids. Lett. Appl. Microbiol. 2007, 44, 619-624. [CrossRef] [PubMed]

63. Se-Ri, K.; Kim, W.-I.; Jae-Hyun, Y.; Do-Yong, J.; Song-Yi, C.; Injun, H.; Nagendran, R. Growth survival of Listeria monocytogenes in Enoki Mushroom (Flammulina velutipes) at different temperatures and antilisterial effect of organic acids. J. Food Hyg. Saf. 2020, 35, 630-636. [CrossRef]

64. Concha-Meyer, A.; Eifert, J.D.; Williams, R.C.; Marcy, J.E.; Welbaum, G.E. Listeria monocytogenes survival in the presence of malic acid, lactic acid or blueberry extract. J. Berry Res. 2017, 7, 33-41. [CrossRef]

65. Mani-López, E.; García, H.S.; López-Malo, A. Organic acids as antimicrobials to control Salmonella in meat and poultry products. Food Res. Int. 2012, 45, 713-721. [CrossRef]

66. Eswaranandam, S.; Hettiarachchy, N.S.; Johnson, M.G. Antimicrobial activity of citric, lactic, malic, or tartaric acids and nisinincorporated soy protein film against Listeria monocytogenes, Escherichia coli O157:H7, and Salmonella Gaminara. J. Food Sci. 2004, 69, FMS79-FMS84. [CrossRef]

67. Raybaudi-Massilia, R.M.; Mosqueda-Melgar, J.; Soliva-Fortuny, R.; Martín-Belloso, O. Control of pathogenic and spoilage microorganisms in fresh-cut fruits and fruit juices by traditional and alternative natural antimicrobials. Compr. Rev. Food Sci. Food Saf. 2009, 8, 157-180. [CrossRef]

68. Yoon, J.-H.; Jeong, D.-Y.; Lee, S.-B.; Choi, S.; Jeong, M.-I.; Lee, S.-Y.; Kim, S.-R. Decontamination of Listeria monocytogenes in king oyster mushrooms (Pleurotus eryngii) by combined treatments with organic acids, nisin, and ultrasound. LWT-Food Sci. Technol. 2021, 144, 111207. [CrossRef]

69. Wang, Y.; Lee, S.M.; Dykes, G. The physicochemical process of bacterial attachment to abiotic surfaces: Challenges for mechanistic studies, predictability and the development of control strategies. Crit. Rev. Microbiol. 2015, 41, 452-464. [CrossRef] [PubMed]

70. Park, S.-H.; Kang, D.-H. Influence of surface properties of produce and food contact surfaces on the efficacy of chlorine dioxide gas for the inactivation of foodborne pathogens. Food Control 2017, 81, 88-95. [CrossRef]

71. Liao, C.-H.; Sapers, G.M. Attachment and growth of Salmonella Chester on apple fruits and in vivo response of attached bacteria to sanitizer treatments. J. Food Prot. 2000, 63, 876-883. [CrossRef] [PubMed]

72. Kaczmarek, M.; Avery, S.V.; Singleton, I. Microbes associated with fresh produce: Sources, types and methods to reduce spoilage and contamination. Adv. Appl. Microbiol. 2019, 107, 29-82. [CrossRef] [PubMed]

73. Silva, A.A.d.; Gonçalves, R.C. Reactive oxygen species and the respiratory tract diseases of large animals. Ciência Rural 2010, 40, 994-1002. [CrossRef]

74. Adhikari, A.; Syamaladevi, R.M.; Killinger, K.; Sablani, S.S. Ultraviolet-C light inactivation of Escherichia coli O157: H7 and Listeria monocytogenes on organic fruit surfaces. Int. J. Food Microbiol. 2015, 210, 136-142. [CrossRef] [PubMed]

75. Yan, S.; Luo, Y.; Zhou, B.; Ingram, D.T. Dual effectiveness of ascorbic acid and ethanol combined treatment to inhibit browning and inactivate pathogens on fresh-cut apples. LWT-Food Sci. Technol. 2017, 80, 311-320. [CrossRef]

76. Gao, J.; Luo, Y.; Turner, E.; Zhu, Y. Mild concentration of ethanol in combination with ascorbic acid inhibits browning and maintains quality of fresh-cut lotus root. Postharvest Biol. Technol. 2017, 128, 169-177. [CrossRef]

77. Hoelzer, K.; Pouillot, R.; Van Doren, J.M.; Dennis, S. Reduction of Listeria monocytogenes contamination on produce-a quantitative analysis of common liquid fresh produce wash compounds. Food Control 2014, 46, 430-440. [CrossRef]

78. Fan, X.; Huang, R.; Chen, H. Application of ultraviolet $C$ technology for surface decontamination of fresh produce. Trends Food Sci. Technol. 2017, 70, 9-19. [CrossRef]

79. Yun, J.; Yan, R.; Fan, X.; Gurtler, J.; Phillips, J. Fate of E. coli O157: H7, Salmonella spp. and potential surrogate bacteria on apricot fruit, following exposure to UV-C light. Int. J. Food Microbiol. 2013, 166, 356-363. [CrossRef] 